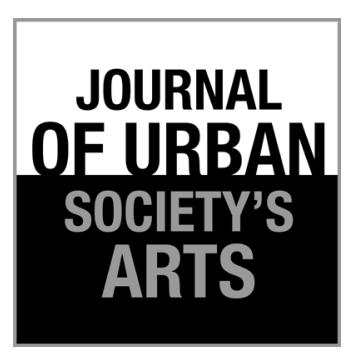

Volume 7 Nomor 1, April 2020: 1-8

\section{Deconstruction and Fractalization of Urban Identity}

\author{
Mojtaba Valibeigi \& Faezeh Ashuri \\ Urban Planning Department, Buein Zahra Technical University, Qazvin, Iran \\ Email: mojtaba.valibeigi@bzte.ac.ir; HP.: +989120593514
}

\begin{abstract}
In this paper, we report on deconstruction of urban semantics in Ellamite city. It is significant because how the city's identity has acquired a semantic significance beyond its significance what is still to be seen. The research, by referring to the Dur Untash city at the Symbolic level, seeks to answer the question on how in urban semiotics, the city's identity has acquired a semantic significance beyond its significance. The situation of the city expresses a state that any kind of dominant discourses has lost their accreditation capacity and authority, and the audience cannot rely on any of the currents that were considered as definitive. City identity is nothing but fractal games that there is no source of authority that indicates the fixed meaning of these formulas, and it is a social contract. These contracts derive from the semiotic rules which is agreed upon in the community. In this game, we tried to impose certain meanings on the city identity using the symbolic function; to internalize metanarrative (internalization process) and in this way, the identity and the presence of the Dur-Untash city will be recorded in time and reach an immortal realm.
\end{abstract}

Keywords: urban deconstruction; urban semantics; urban identity; urban symbolism; fractalization of urban meaning

\begin{abstract}
ABSTRAK
Dekonstruksi dan Fraktalisasi Identitas Perkotaan. Makalah ini membahas tentang dekonstruksi semantik perkotaan di kota Ellamite. Ini penting karena bagaimana identitas kota telah memperoleh makna semantik di luar signifikansinya, dan apa yang masih harus dilihat. Penelitian ini, yang mengacu pada kota Dur Untash pada level simbolik, berusaha menjawab pertanyaan tentang bagaimana dalam semiotika perkotaan, identitas kota telah memperoleh makna semantik di luar signifikansinya. Situasi kota mengungkapkan bahwa wacana dominan apa pun telah kehilangan kapasitas dan otoritas akreditasi, dan penonton tidak dapat mengandalkan salah satu arus yang dianggap definitif. Identitas kota tidak lain adalah permainan fraktal yang tidak ada sumber otoritas yang menunjukkan makna tetap dari formula-formula tersebut, dan ini adalah suatu kontrak sosial. Kontrak ini bersumber dari aturan semiotik yang disepakati dalam komunitas. Dalam permainan ini, kami mencoba menekankan makna tertentu pada identitas kota dengan menggunakan fungsi simbolik; untuk menginternalisasi meta-narrative (proses internalization) dan dengan cara ini, identitas dan keberadaan kota Dur-Untash akan terekam dalam waktu dan mencapai alam abadi.
\end{abstract}

Kata kunci: dekonstruksi perkotaan; semantik perkotaan; identitas perkotaan; simbolisme perkotaan; fraktalisasi makna perkotaan

\section{Introduction}

Deconstruction shows a complex respond to a theoretical variety and very prominent philosophical movements in 20th century as the phenomenology of Husserl, de Saussure,
Ferdinand, French structuralism and Lacan psychoanalysis and how the plural logic emerges from out of the relative ruin of the transcendental tradition (Cixous 1994; Hurst 2008). A constant reminder of the etymological link between 'crisis' and 'criticism'. It makes manifest the fact that any 
radical shift of interpretative thought must always come up against the limits of seeming absurdity. Philosophers have long had to recognize that thinking may lead them inescapably into regions of skepticism such that life could scarcely carry on if people were to act on their conclusions (Norris and Roden 2003). Also deconstruction can be seen in part as a vigilant reaction against this tendency in structuralism thought to tame and domesticate its own best insights. Some of Jacques Derrida's most powerful essays are devoted to the task of dismantling a concept of 'structure' that serves to immobilize the play of meaning in a text and reduce it to a manageable compass.

All concepts are contradictory for Derrida. If sentences in language are indefinite, and therefore contradictory, then the concept of the sentence is contradictory, since the sentence must both be what takes meaning and what cannot take meaning. The sentence cannot be isolated as a meaning unit from its context, so that is does not exist in a stable self-identical way, as the same sentence may have different meanings in different contexts. The sentence must both be what it is and not what it is. The same applies to all aspects of meaning. The contradiction is sharper in the Derrida's account than in the Ludwig Wittgenstein account, where contradiction arises implicitly from the variable context of sentences. There is no escape from contradiction in Derrida through looking at the different possible meanings as different usages in different clearly individuated language games, which is one way of reading Wittgenstein in order to effort the exclusion of contradiction (Wittgenstein 2010).

The idea of distinct language games does not exist in Derrida, and even in Wittgenstein they overlap so that the possibility of contradiction cannot be ignored. All sentences are necessarily contradictory in Derrida's account, because they both mean and do not mean according to a distinct meaning content within the sentence that shapes it (Stocker 2006), see also (Staten 1986), (Lacey 2002), (Richter 2004). Deconstruction considers how philosophical texts, when setting the definition as the starting point, do not pay attention to this fact that all these behaviors which led to definition, have an inner order, the order in which everything has been defined due to what was not before it (Evans 1991, Wood and Bernasconi 1988).

Derrida is part of a skeptical tradition; he defines his goal as confronting the philosophical with the empirical in order to question the philosophical. However, Derrida is not a sceptic in the severe sense. The severe sense of skepticism must contain at least two points: first, the complete denial of knowledge of reality itself, usually on the grounds that no knowledge allegations have assurance guaranteed certainty; second, in the sense that we deny a large part of what is taken as evidence of the nature of reality, and this skeptical movement is often followed by the constructive movement in which something better is offered as evidence of reality (Stocker 2006, Williams 2001, Naas 2003). In a text that its foundation is broken, the superiority of one meaning than the opposite one disappears. Accordingly, the text is multimeanings; and because of countless interpretations, the final meaning has been lost(Freshwater and Rolfe 2004, Wood 1992, Julian 1998, Derrida 1993, Payne 1993).

Derrida showed that all texts are based on dual orders, such as existence/non-existence, man/ woman. Where the first member of each pair is considered as a meaning and have a preference. In all those schools of thought, there is a hypothetical vantage core or an Archimedean point; Just that hypothetical vantage core was placed on deconstruction sights, useless and non-hierarchical of that was revealed, and what was considered constant and logical, became unreasonable and void, and the interpretation by itself contains many misconceptions (2003).

\section{Symbol, Semantics and Authority Interpretation as the Inner Dominant Aspect}

Urban semiotics relate the joint of ideology and power structures with human urban space. And analysis propose is investigation of public imagination and meaning code articulated with space (Pipkin, La Gory, and Blau 1983, Gottdiener and Lagopoulos 1986). Accordingly social semiotics have a key role in recognition of public 
understanding in looking to space that including social connotations(Keller 1988). Consequently, the space are known when symbolic meaning and its complex impact on human behavior have been recognized and the space has a potential for combining geographic and social imagery with all its complexity(Harvey 2010, 1970). There is an essential principle in art and architecture that spatial forms can be applied in different ways, in this way, is induced various symbolic meanings. If the city contains signs and symbols, then the meaning of these symbols can be understood by people; we should seek to understand the meaning that people receive from their built environment (Knox 1984).

The urban space is not only a face of the economic and political power put on different times by various societies; it is also a means by which the dominant structure of power and socioeconomic relationships are continued (Gieseking et al. 2014). Accordingly, city defined as a language written by built world and read by its citizens through cognitive imaging (Barthes 1967, 1994). At this time, what kind of meaning is linked to the city and by what kind of mechanism? (Krampen 2013) have a key role in interpretation of urban semantics. The design of a medieval church simply shows the nature of the social hierarchy, through the spatial relationship of a person with the central focal point. It is no coincidence that the people in the altar are closer to God than those sitting in the hall. Where can be seen a demonstration of the social order nature and the nature of social processes (Harvey and Braun 1996).

Through physical and movement processes, the city allows people to make a difference in their daily routine experience and by doing so in urban space, contradistinction is done. And the difference is considered both as a factor for identification and recognition and as a value that is placed among many aspects of the city such as poverty and wealth, good and bad, proper and inappropriate, ugly and beautiful.

What the city is looking for, what people and different social groups are looking for in the city, is the creation of meanings and differentiations. Meanings and different result from mental and social processes and power structures. A prominent interpretation that we would like to accept and internalize; an idea which roots in desire. The city is trying to induce and create it, but from deconstruction's view any symbolism in order to create it both in individual or social authority level is doubtful.

By frustrating urban meanings, deconstruction is trying to eradicate the boundary between opposite concepts and see it as one-dimensional ones. Based on, in this perspective, within each city, there are two types of cities: the first city, the city was formed by the authority of that time and understood and interpreted on this basis. And its logic and truth can be found; everything in it has been reduced to the double contradictions like persistence/instability, real/non-real. Or it is a dominant and authoritative interpretation of urban symbols or critical interpretation.

An interpretation of authority structures and social processes can be investigated. Depending on the interpretation, understanding the symbolic meaning of space be subject to a certain single unit idea. Referring to that general idea, spatial meanings are understood. What makes sense of the concepts of superiority, control, domination, authority, exploitation, and so on through the game of social contracts and social hierarchies. But it also has the second city, which is freed from the double contradictions; the logic, and truth cannot be found in it, and with the roots destructing of its symbolic meaning, does not have mean, and the first city is the sign for this second city. In other words, when we want to perceived city in terms of a symbolic function; since city acts at the symbolic level, affected of social process and authority; works on the action of repeating something that has already been said or extends over so as to cover partly, provide to experience a change in form or phenomenon or be a concise version of something, has become internally differentiated (Wood 2012, D’Cruz 2016, Gabriel 2013, Abbinnett 2003).

\section{Choga Zambil: Manifestation and Duality of Sense of Life}

The city as the first form of civilization and the center of holiness, power and wealth always has 
been an ideal and sacred meaning. It has tended to portray its socio-philosophical aspirations towards the future and its destination that led to the emergence of different ideals (Morris 2013, Nas 2016, Seasoltz 2005). Several studies have shown the definitive impact of subject of the worldview on genesis city of Dur Untash and its life center (Rohl 1999, Ghirshman 1961). Valuing and sacred markings in the city, naturally have guarantee and continuity mechanisms that can re-generate or vice versa can eliminate and degradation semantic loads over time.

Dur Untash basically were created as symbolic centers of ceremonies. Thus, the city is a symbol of the world and it has the power to organize and regulate wider areas (Potts 2006, Bryce 2009, Osborne 2014). Generally, the city has the fundamental principles to which it refers: The center of the world being against being subordinate; a manifestation of perfection and divine order in contrast to the external world's disorder; Eternal presence and stability versus instability, mortality.

The city is recognized and validated according to a series of holy ceremonies such as many early ancient city and the city and its holy buildings are built on the basis of a philosophy that comes from the beliefs of men. And this creates a critical interpretation of the structures of power and social processes of domination and a deconstruction of the cause of the tendency toward such structures in historical trend.

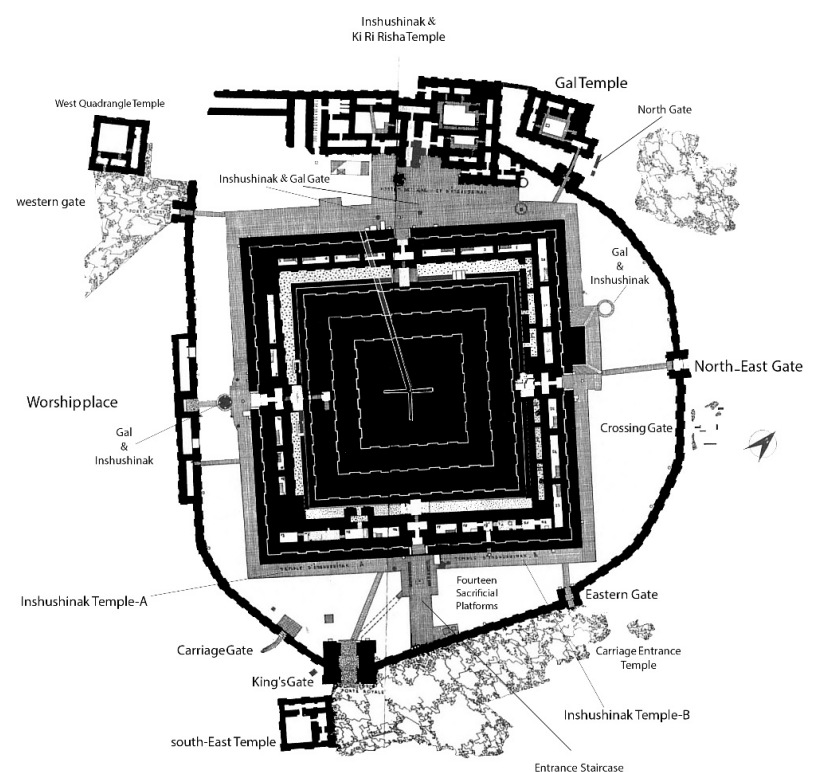

Figure 1. Plan of The Choga Zambil's Ziggurat.
The ancient Choga Zambil site is located at $48^{\circ}$ and $30^{\prime}$ minutes longitude and $32^{\circ}$ latitude in Khuzestan and in the southeastern part of the Shush city and is located on a part of Taghdis Sardarabad of Zagros Mountain Range. The ancient city of Dur Untash or the historical site of Choga Zambil in the 13 th century $\mathrm{BC}$ was built by the Elamite ruler Untash-Gal during the Middle Elamite period (c. 1500-c. 1000 BCE)(Britannica 2018). The city's spaces separated by three concentric walls, in which in the center of them there is an elevated temple or so-called Ancient Temple, "ziggurat ". The temple was given to two of the great Elamite gods, Inshushinak and Napir. Choga Zambil's ziggurat is the same holy buildings that in which elements of thought blend with holiness are seen. The Choga Zambil's ziggurat is a multi-story building, squareshaped that first floor is larger and wider than the upper floors. There are circular walls around this square-shaped building that is a remembrance of the combination of squares and circles in this sacred building (see fig1) (Fisher and Shivers 2008). In this respect, the Choga Zambil's ziggurat is similar to the Kaaba's home. Kaaba's home is a black building and square-shaped (cubic) that Muslims go around circular the Kaaba with the white ihram clothes.

The Square-shaped building of Choga Zambil with Circular fences are reminded the number four as a sacred number in architecture. Four in the ancient is a symbolic numeral. Like the four rivers in paradise that are cross-shaped; four sections of the earth, and so on. From the farthest ages, four was used to represent what is strong, tangible and sensible. Four is somehow a divine number.

Number four can be observable in religious architecture a lot. The planes drawn from paradise are square-shaped (rectangular) and have four doors. The Choga Zambil's ziggurat has four entrance doors and the directions of the ziggurat corners are matched to four main directions: the north, south, east and west. Finally, The Choga Zambil's ziggurat is surrounded by circular fences. The fence, the wall and the ring of rattles that cover the sacred places are among the oldest architectural structures of the shrines.

The shaped construction of the Ziggurat, Pyramids, Stupas, Pagodas and Mandala, all of 
which are considered sacred buildings, follows a similar ideas. In all of these buildings, the tall buildings, rush from the ground to the sky and from the carpet to the throne, which is somehow reminiscent the mountains, and all of them, the sacred spaces, are portrayed are in the center of the universe. According to the Islamic beliefs, in the "Mojmal al-tawarikh" (Bosworth 1968) and other sources, it has been mentioned that the angels have brought the rocks of the Kaaba's home from the five holy mountains and have brought HajarSalood from Paradise. It is clearly mentioned the five mountains names like Mount Sinai, Mount of Olives, Mount Judi and Mount Hira. These mountains have been considered sacred because they are observable by God and the prophets came to them: like Mosa and Mount Sinai, Noah and Mount Judy, Isa and Mount of Olives, Muhammad and Mount Hira.

In fact, the ziggurats, pagodas and stupas were everywhere symbolic of the mountains and the sky. The people who came from the eastern land and lived in the plains, could not bring their mountains to the new land, so in the flat land of the Middle East, they placed large ziggurat instead of holy mountains (figure. 2). The temple's likeness to the cosmic mountains has a special place in Babylonian culture and this characteristic can be seen in the shape of their ziggurat, which saw the ascent of it, is reach to the summit of the universe, the stairways to heaven. The ziggurat or ziggurat word is taken from the Acedi, Zegharoo meaning, lift up or raised (Wales 1953).

Each floor is smaller than the lower floor; therefore, the facade of each side have a staircase form. This ziggurat were the place for keeping statues of gods and performing religious ceremonies. The highest temple on the highest floor of the

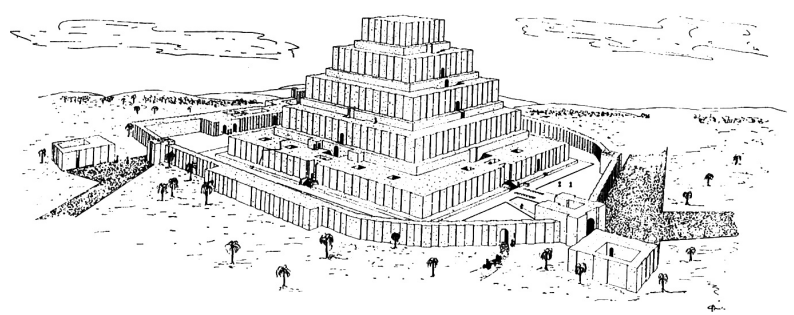

Figure 2. The Image reconstruction of Skyline and ziggurat in Khuzestan plain. Source: Rebuilt plan of Ghirshman (1961). ziggurat seems to keep the god statues of Napir and Inshushinak in this temple. There are stairs in the middle of each floor on the four sides of the ziggurat, each of them is blocked by gates. These stairs were the ways to going higher classes. (See figure 3).

In 640 BCE, Ashurbanipal, the powerful king of Assuyria, seized Elamite city. Elamian people died and their government was destroyed, and the temple of Choga Zambil turned into a mountain. The holly mountain was formed from the complete destruction of the Dur Untash city or the historic site of Choga Zambil (figure 4). Elam was wiped off the page. In 1935, the aerial phohos of AngloIranian Oil Company revealed the strange shape of the Choga Zambil hill. Experts believed that the hill could not be normal, and the hill would again be turned into a temple.

\section{Deconstruction of a Forgotten Ziggurat}

Man tries to create sense of his/her lives that the ways in which man do this are subject to crossquestion and doubt both from himself/herself and others, that she/he is mortal and know it, and that she/he wants her/him lives to be publicly as well as privately intelligible. But more significantly, that the means available to make such sense are becoming increasingly imperfect, defective, faulty, malformed unreliable and local (Wood, 2012). Choga Zambil is a sample for such a desire and such a mean.

The city implicitly refers to a culture that city is a symbol for the elimination of instability; in fact, the symbol of the absence that it tries to present. The lost one, which is every time try to prove its presence. In other words, symbols founded the city, which apparently, are the manifestation of the divine

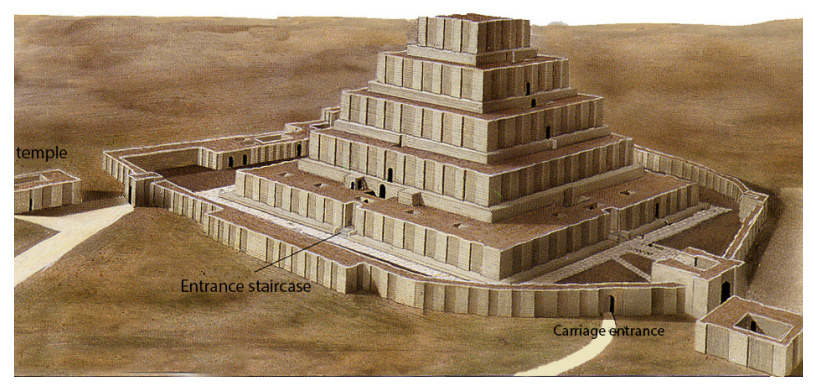

Figure 3. Entrances and stairways to heaven. 
presence of the Dur Untash city, also are an attempt to overcome the fear of instability and death that is produced and reproduced by the city every moment and shows itself in an inexhaustible experience; A reaction against the feeling of instability and absenteeism and concealment and negation it; An attempt to A stable definition of self in the same deformation; consciously and unconsciously, a creation of a sustainability sense by symbols and concepts function. By the way, what is certain is that no intelligibly intuition of Dur Untash identity will do that fails to acknowledge and Dur Untash city has become spiral even fractal.

Mountain idea which was the symbol of the city, was the answer to their absence, away from them. Mountain idea return to a mountain but in away from them, their absence.

The city is described as a symbol of the world's order, the texture of the gates, walls, street order, the location of the city center and its nature are all aspects of the astrobiology (or the biological review of the supernatural beings). In this insight the sacredness are real and as a result, only sacredness are safe. Biological complexes and buildings are similar to their celestial examples, and they must be sacred before making up as a living space, and this could be done by establishing a connection between heaven, earth, and the underworld.

The city wants to be lean to such things, it is pleasing, but what has been gathered as a city is only a fractalization act. The city wants to state that is moving in a definite and stable framework, Even if it cannot create and induce it both internally and externally; makes fractal so much to cover its identification and his confusion; a complexity

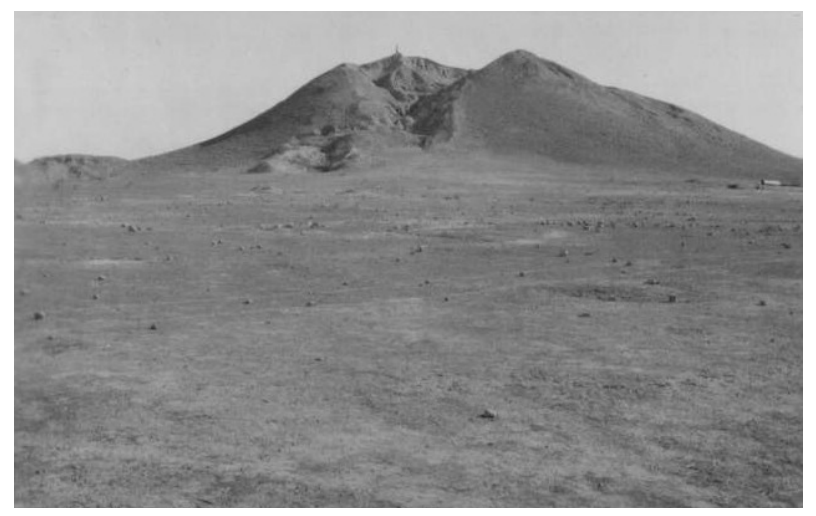

Figure 4. Memory experience or become original. Source: choghazanbil.ir process. What the city is looking for; what the people of the city are looking for, are rooted in the dreams and desires that the city is trying to fulfill. But every compilations, any symbolism and whatever the city tries to deny, continues at the same time in the city. In fact, the city was a fractal for men.

Choga Zanbil's painful image have been arised when we grasp to things that make me gratification, for then we are afraid of anyone or anything that may take them away from me, at the moment, the roots of the it's symbolic concept collapse. In as much as the symbolic concept roots are not deconstructed, the psychological gatherings prevent psychological pain. Until there is enthusiasm and hope, there is always the background of fear. After many years, still also can observed that Choga Zambil afraid of anyone/anything that disturbs it and lost the accumulated known. Chains of known and compassed stimulus, and the past that has been given to life through the present. Where through labeling, naming and remembering from time feeds. Memory of various experiences which have produced and reproduced names, labels, identifications and according to the memory of experience have been determined to be or not to be. When an experience was gained, it is over, it is dead. It cannot be repeated. What can be repeated is the sensation and the corresponding word that gives life to that sensation. But what's the difference between the two for Choga Zambil: life or life sensation.

Choga Zambil seems to be very humble and simple, but inwardly it's prisoners. Now, what's left of it, except memory? A memory that follows to a pattern of authority. It still likes to stay

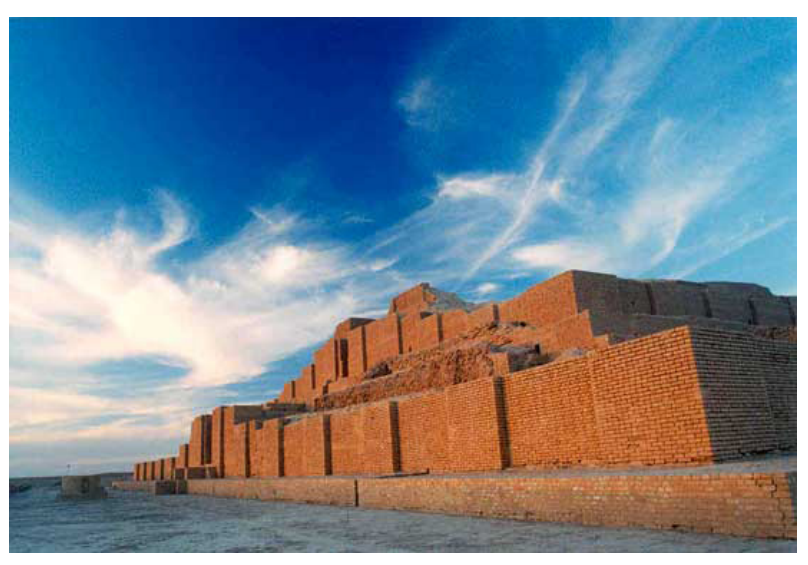

Figure 5. Life or life sensation. 
alive, by showing the innumerable impediments, attachments, fears, dreams and ideas, what the play of its death is; a mechanical process of excitement and memory. That it is sensation and desire, and that it is mechanically caught up in routine.

\section{Conclusion}

A constant state of denial and assertion; a continuous fight to become something apart from what it is. This is Dur Untash city, and it want to be that (Ideal); a play of This \& That. An interesting process seen in each element that including a memorizing something and trying to overlook it in order to find something new. That is to say there is a chase overcoming another chase. A seemingly permanent state which is being resisted by another temporary state. Choga Zambil is a means to such an outcome; and until the time comes, contradiction continues. A monuments for find truth to achieve permanent gratification or a symbol for seeking lasting satisfaction not for seeking truth. Choga Zambil is a cover with an idea, a respectable-sounding word for that fleeting pleasures and unflattering delusion. In return, such contradiction gives us a motivation and push to live; every resistance symbols creates a sense that life goes on; a sense of vitality. Finally Choga Zambil is simply the crystallization of an idea as a symbol and the effort to live up to the symbol brings about a contradiction. A play is of a concern with pleasure and the avoidance of pain and its capacity' is try to create such an image; the simultaneous presence of pain and pleasure.

\section{References}

Abbinnett, Ross. (2003). Culture and identity: critical theories. USA: Sage.

Barthes, Roland. (1967). "Elements of semiology (A. Lavers \& C. Smith, Trans.).” New York: Hill and Wang.

Barthes, Roland. (1994). The semiotic challenge: USA: Univ of California Press.

Bosworth, Clifford Edward. (1968). "The Development of Persian culture under the early Ghaznavids." Iran 6 (1):33-44.
Britannica, The Editors of Encyclopædia. (2018). Choghā Zanbīl. In Encyclopedia Britannica: Encyclopædia Britannica, inc.

Bryce, Trevor. (2009). The Routledge Handbook of the Peoples and Places of Ancient Western Asia: The Near East from the Early Bronze Age to the Fall of the Persian Empire: USA: Routledge.

Cixous, Hélène. (1994). The Hélène Cixous Reader. USA: Psychology Press.

D'Cruz, Carolyn. (2016). Identity politics in deconstruction: calculating with the incalculable. USA: Routledge.

Derrida, Jacques. (1993). Jacques Derrida. translated by Geoffrey Bennington. Chicago: University of Chicago Press.

Evans, Joseph Claude. (1991). Strategies of Deconstruction: Derrida and the Myth of the Voice. USA: University of Minnesota Press.

Fisher, David, and Olin Shivers. (2008). "Building language towers with Ziggurat." Journal of Functional Programming 18 (5-6):707-780.

Freshwater, Dawn, and Gary Rolfe. (2004). Deconstructing evidence based practice. California: Psychology Press.

Gabriel, Fleur. (2013). "Deconstruction and the Question of Identity." In Deconstructing Youth, 51-69. London: Springer.

Ghirshman, Roman. (1961). "The Ziggurat of Tchoga-Zanbil." Scientific American 204 (1):68-77.

Gieseking, Jen Jack, William Mangold, Cindi Katz, Setha Low, and Susan Saegert. (2014). The people, place, and space reader. USA: Routledge.

Gottdiener, Mark, and Alexandros Ph Lagopoulos. (1986). The city and the sign: An introduction to urban semiotics. Columbia: Columbia University Press.

Harvey, David. (1970). "Sosial Processes and Spatial Form: An Analysis of the Conceptual Analysis of the Conceptual Problems of Urban Planning". Papers in Regional Science 25 (1):47-69. doi: 10.1111/j.1435-5597.1970. tb01477.x.

Harvey, David. (2010). Social justice and the city. Vol. 1. USA: University of Georgia Press.

Harvey, David, and Bruce Braun. (1996). Justice, nature and the geography of difference. Vol. 468: 
Wiley Online Library.

Hurst, Andrea. (2008). Derrida Vis--vis Lacan: Interweaving Deconstruction and Psychoanalysis. USA: Fordham University Press.

Julian, Wolfreys. (1998). Deconstruction: Derrida. USA: Macmillan.

Keller, Suzanne. (1988). Review of The City and the Sign: An Introduction to Urban Semiotics., Mark Gottdiener, Alexandros Ph. Lagopoulos. Contemporary Sociology 17 (3):346-348. doi: 10.2307/2069642.

Knox, Paul. (1984). "Symbolism, styles and settings: the built environment and the imperatives of urbanized capitalism." Architecture and Behaviour 2 (2):107-122.

Krampen, Martin. (2013). Meaning in the urban environment: Routledge.

Lacey, Alan. (2002). Dictionary of philosophy: Routledge.

Morris, Anthony Edwin James. (2013). History of urban form before the industrial revolution: Routledge.

Naas, Michael. (2003). Taking on the tradition: Jacques Derrida and the legacies of deconstruction: Stanford University Press.

Nas, Peter JM. (2016). Cities full of symbols: a theory of urban space and culture: Leiden University Press.

Norris, Christopher, and David Roden. (2003). Jacques Derrida. Vol. 3: Sage.

Osborne, James F. (2014). Approaching monumentality in archaeology: SUNY Press.
Payne, Michael. (1993). "Reading Theory an Introduction to Lacan, Derrida, and Kristeva." Pipkin, John, Mark La Gory, and Judith R Blau. (1983). Remaking the City: SUNY Press.

Potts, Daniel T. (2006). "Elamites and kassites in the persian gulf." Journal of Near Eastern Studies 65 (2):111-119.

Richter, Duncan J. (2004). "Ludwig Wittgenstein.”

Rohl, David M. (1999). A Test of Time: Legend: the Genesis of Civilisation: Arrow.

Seasoltz, R Kevin. (2005). A sense of the sacred: Theological foundations of Christian architecture and art: A\&C Black.

Staten, Henry. (1986). Wittgenstein and Derrida: U of Nebraska Press.

Stocker, Barry. (2006). Routledge philosophy guidebook to Derrida on deconstruction: Routledge.

Wales, HG Quaritch. (1953). "The Sacred Mountain in the Old Asiatic Religion 1." Journal of the Royal Asiatic Society 85 (1-2):2330.

Williams, Michael. (2001). "Problems of knowledge: A critical introduction to epistemology."

Wittgenstein, Ludwig. (2010). Philosophical investigations: John Wiley \& Sons.

Wood, David. (1992). "Derrida: a critical reader."

Wood, David. (2012). Step Back, The: Ethics and Politics after Deconstruction: SUNY Press.

Wood, David, and Robert Bernasconi. (1988). Derrida and Différance. Evanston: Northwestern University Press. 